Social Class and Serum Uric Acid

M. G. Cook, M.B., and others; R. Finn,

M.D.
udden Death after Exertion

M. McCormack, M.B. ; D. C. L. Savage,
M.R.C.P. $\ldots \ldots \ldots \ldots \ldots \ldots \ldots \ldots \ldots \ldots \ldots \ldots \ldots \ldots \ldots \ldots \ldots \ldots \ldots \ldots \ldots \ldots \ldots$

M.R.C.P.
Congenital Anomalies of the Vas Deferens

Congenital Anomalies of the Vas Deferens
R. E. B. Tagart, F.R.c.s. ..................233

R. E. B. Tagart, F.R.C.S. ..............
Warning to Travellers to Tanzania

G. H. Robb, M.R.C.P. ..................233

Exposure and Exhaustion

G. A. Ballance, M.B.

Awareness during Anaesthesia

J. M. Leigh, F.F.A. R.C.S., and C. $M$.

Morriss, F.F.A. R.C.S.

Carbenicillin Resistance in Pseudomonas aeruginosa

W. A. Black, M.B., and R. W. A. Gird

wood, M.B. ................................2 234
Tennis Leg

D. Golding, M.D.

Fibrin Degradation Products

C. Merskey, 234

Pituitary Dwarfism and Size of Gonads

Z. Laron, M.D., and R. Sarel, M.D. ........235

Formaldehyde Sterilization for Dialysers

M. Murray, M.R.C.P., and others ........235

Potassium Iodide in Bronchial Asthma

Christine Bernecker, M.D. ................2236

Inappropriate Lactation

M. Segal, M.R.c.P.GLASG., and R. F. Heys,

M. Segal, M.R.C.P.GLASG., and R. F. Heys, 236

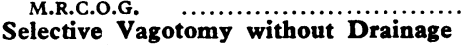

F. I. Tovey, F.R.c.s. ....................236

Routine Tranquillizers in Obstetrics

A. M. Blain, M.B. .......................237

Systemic Corticosteroid Therapy

E. J. Ross, F.R.C.P.
Little Strokes

R. S. Stevens, M.D. ...................237

Unusual Effect of Fenfluramine

M. Y. Alvi, M.B. ...............

Drug Seeker

M. E. Gill, м.в. ....................237

Antivenom Stocks for Adder Bite

H. A. Reid, M.D., D.T.M.\&H. ............237

Filming during Anaesthesia

P. N. Cardew, M.R.c.s. ................237

New Consultant Surgeon in Shrewsbury

Group

Aroup

.237

Representation of Hospital Junior Doctors

J. F. G. Pigott, F.F.A. R.C.S. ; Surgeon Lieut.-
Commander D. S. Wright, D.P.H. ; W. J

Commander D. S. Wright, D.P.H. ; W. J.
Appleyard, B.M. ; J. A. J. Macleod, D.C.H. 238

The Consultant's Job

J. W. Paulley, F.R.C.P. .....................239

\title{
Social Class and Serum Uric Acid
}

SIR,-Those of us with concentrations of uric acid in the plasma which are above the average will not easily abandon the conclusions of the Michigan group that in males an increased uric acid correlates with "intelligence and excellence of all-round performance" 1 or even "drive, achievement, and leadership." 2 Professor Acheson's observation that uric acid in males does not correlate with social class (11 October, p. 65) is not incompatible with these earlier findings; as he pointed out, the groups studied in Michigan were not representative of the social classes they occupied.

We have examined 54 samples of plasma collected from male laboratory workers for haematological screening during the study of normal ranges for uric acid in a variety of hospitals and other populations. The values were divided into two groups: "doctors"both in the sense used by this journal and in the university. sense-and " non-doctors," largely technical staff. (The Registrar General promoted the former group from Class II to Class I, and the latter Group from Class III to Class II in 1960.) The mean uric acid concentrations were $6.25 \mathrm{mg}$./ $100 \mathrm{ml}$. for laboratory doctors and $5.60 \mathrm{mg}$./ $100 \mathrm{ml}$. for other laboratory workers. The difference, which could not be attributed to age or obesity, was significant $(P<0.05)$.

Uric acid may still be higher in those who have achieved a higher social class, and Professor Acheson's failure to demonstrate a correlation may be due to their dilution by those whose social position depends upon birth or outside influences (cf. Malvolio ${ }^{8}$ ).-We are, etc.,

M. G. Coor.

M. J. LeVell.

Department of Chemical Pathology,

R. B. Payne.

University of Leeds.
REFERENCES

I Dunn, J. P., Brooks, G. W., Mausner, J., Rodnam, G. P., and Cobb, S., foumal of the American Medical Association, $1963,185,431$
Brooks, G. W. and Mueller B., fournal of the

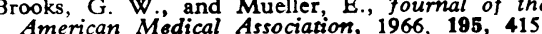
American Medical Association, 1966, 195, 415
Shakespeare, W., Twelfth Night, Act 2, Scene 5

SIR,-Professor R. M. Acheson (11 October, p. 65) draws attention to the many conflicting reports concerning the epidemiology of serum uric acid levels including the relationship to social class and intelligence. We have previously suggested ${ }^{1}$ that the confusion in this subject is largely methodological. It is not sufficiently appreciated that the chemical estimation of uric acid is subject to several variables, such that different laboratories tend to record different results on the same sample of blood, and that the same laboratory may record different values using different batches of reagents over an extended period of time. ${ }^{2}$

We attempted' to overcome this difficulty by storing all samples in the frozen state, and then analysing them together at the completion of the survey in a continuous AutoAnalyzer run utilizing the same reagents throughout together with multiple standards. Using this technique it was concluded that the serum uric acid level was polygenically determined, and that independent genetic loci were also involved in the production of clinical gout in a hyperuricaemic subject. There is evidence that in some families an arthritis-producing factor may act as a genetic dominant. This concept fits with the clinical observation that many cases of marked hyperuricaemia do not show clinical gout and conversely that severe arthritis can oocur in subjects who are not grossly hyperuricaemic.

It is evident, therefore, that large-scale surveys of uric acid should be carried out with these technical considerations in mind. Serum samples from the various centres should be stored in the frozen state, and then analysed together at the completion of the survey in a central laboratory, on a single continuous AutoAnalyzer run, utilizing the same batch of reagents and appropriate standards. It will also be necessary to record sex, age, and weight which are known to influence the uric acid level.

Until such time as the methodology of uric acid surveys is tightened up, confusion will continue to reign in this field.-I am, etc.,

RonAld FinN.

Nuffield Unit of Medical Genetics,

University of $\mathrm{L}$

REFERENCES

1 Finn, R., Jones, P. O., Tweedie, M. C. K., Hall, S. M., Dinsdale, O.' F. and Bourdillon, R. B., Lancet, 1966, 2, 185 .
Bywaters, E. G. L., Holloway, V. P., Annals of Rheumatic Diseases, 1964, 23, 236.

\section{Sudden Death after Exertion}

SIR,-I read with interest the communication from Dr. R. C. R. Connor regarding the unexplained death of a healthy young boy (4 October, p. 30). The onset of ventricular fibrillation and other cardiac dysrhythmias with strenuous exercise after ingestion of sympathomimetic agents is a well-known phenomenon, and it would be helpful to know if in this case the taking of such a drug had been definitely ruled out.

A further point to bear in mind is the increasing consumption of large doses of ephedrine by youngsters, this being more readily attainable than amphetamines. Indeed, there appears to be virtually no restriction on its sale.-I am, etc.,

M. MCCORMACK.

Department of Surgical Neurology, Royal Infirmary. 